\title{
Current State of Art Design Education in Colleges and a New Hybrid Learning Mode
}

\author{
https://doi.org/10.3991/ijet.v16i17.25651 \\ Jing Liang $\left({ }^{\varpi}\right)$ \\ Shijiazhuang University of Applied Technology, Shijiazhuang, China \\ xiaoyao_11520@126.com
}

\begin{abstract}
Art design education contributes immensely to social and economic development. To train art designers that suit social development and industrial needs, colleges must substantially reform their art design education. From the perspective of cultivating the core literacy, this paper carries out a survey on the current state of art design education in colleges. The survey reveals the following problems of art design education in Chinese colleges: the students have a poor cultural literacy, a low interest in professional learning, and a weak understanding of the core literacy; the faculty has an unreasonable structure, an overall weak competence, a monotonous teaching method, and the detachment of theories from practices. Based on the survey results, a hybrid learning mode was derived from project-based learning, and the application effect of the proposed mode in art design education was analyzed from the perspective of the cultivation of core literacy. The results show that, the proposed learning mode can effectively enhance teaching quality, and improve the core literacy and professional ability of students. The research provides a valuable theoretical and practical reference for the reform of art design education.
\end{abstract}

Keywords - art design education, current state of education, core literacy, project-based learning, hybrid learning

\section{Introduction}

With the fast pace of globalization and social economy development, now in China, the market competition has become increasingly fierce, and the commodity economy is booming. As a result, Chinese people's living standards have been greatly improved, food and cloth can no longer satisfy their needs, and they have begun to pursue quality material and esthetical appearance. In such a context, the discipline of art design has been pushed to an important position in modern education, and colleges have become the main ground for cultivating art design talents. In recent years, the Chinese education department is constantly deepening the reform of education mode, and colleges with art design major have reformed their teaching mode and education system to varying degrees. Currently, how to train art designers that suit social development and industrial needs have become a focus of attention for professional art design major administrators, teachers, and education experts. 
The education of art design is a concept that is under constant development, and it has gone through a few development stages of craft education, handicraft education, and pattern education [1]. The education of arts and crafts is the predecessor of art design education. Since the 1980s, art education has achieved unprecedented development in China, and the Ministry of Education of China officially changed the name "arts and crafts" to "art design" in 1998 [2]. Now most Chinese colleges have set art design related disciplines, the school size is growing, and the teaching level is improving; however, due to the differences in faculty level, basic facility, student training mode, and school running direction, the art design talents cultivated by different schools are of different competence levels, some of them cannot fully adapt to the society or suit the requirements of the job posts, some of them have to face unemployment right after graduation; however, at the same time, there's a great shortage of designers in the design industry, and the detachment between talent supply and social demand has become more prominent [3]. To solve such dilemma, the education department has vigorously promoted the educational reform in the country, the Chinese colleges have begun to reform their teaching mode, and more and more experts, scholars, and teachers are joining in the research on art design education from different perspectives. Some of them researched the education management system; some studied the topics of talent training goals, ideas, modes, and curriculum setting; and some carried out theoretical and practical research on the teaching models and methods; after their continuous efforts, a wealth of research results has been obtained [4].

In order to establish an art education system that is compatible with the development level of the entire society, this paper drew on previous research results and analyzed the current state of art design education in Chinese colleges from the perspective of core literacy cultivation; then it proposed a project-based hybrid learning mode, and analyzed its actual application effect in art design education in Chinese colleges from the perspective of core literacy, and the research findings of this paper show that the proposed mode is conductive to mobilizing students' learning initiative, and enhancing their core literacy and professional ability.

\section{Current state of art design education in colleges}

In this study, teachers and students from the art design major of 6 colleges in a Chinese province were selected as subjects, and questionnaire survey and interview were combined to investigate the current state of art design education in colleges from three aspects: students, teachers, and teaching methods [5]. After the survey, a total of 632 valid questionnaires for students and 75 valid questionnaires for teachers were returned; all returned valid questionnaires were sorted and the data were counted and analyzed, here is a summary of the survey results:

\section{$2.1 \quad$ Students}

Figure 1 shows the statistics of the reasons for students to choose the art design major. According to the figure, more than $40 \%$ of the students chose this major because 
their college entrance exam scores were not ideal, so they chose the art design major which has a lower requirement for exam scores, only $19.2 \%$ of the respondents applied for this major because they do have an interest in it; also a part of the students think that the art design major has a good employment prospect, good working environment, and a high salary level, and they applied for this major out of these considerations.

Figure 2 shows the statistics of students' art skills before the college entrance examination. As can be seen from the figure, more than $40 \%$ of the students have received special art training for six months to one year before the college entrance examination; $36.5 \%$ of them have participated such training programs for more than one year; and only $14.4 \%$ of them have an experience of more than two years; some students applied for the art design major after only 3 months or even shorter intensive training.

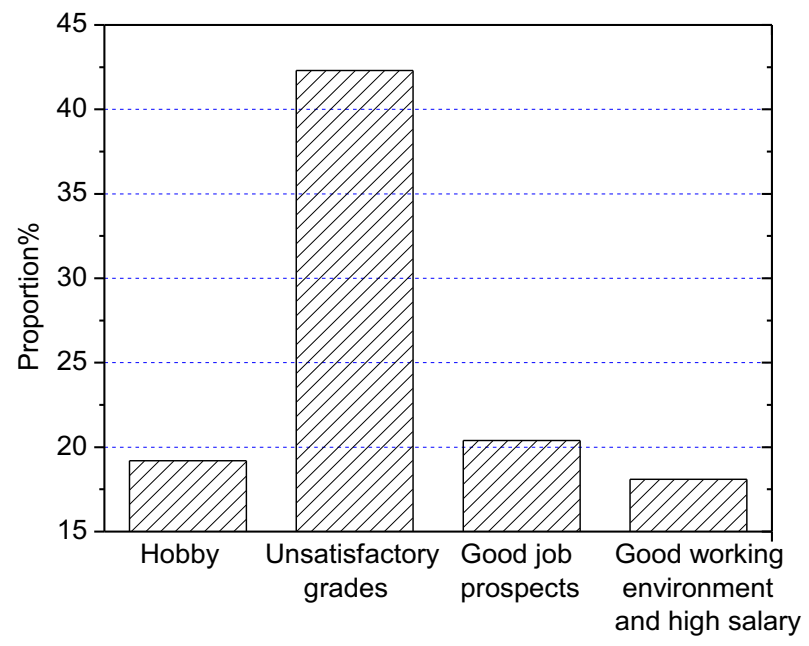

Fig. 1. Reasons for choosing the art design major

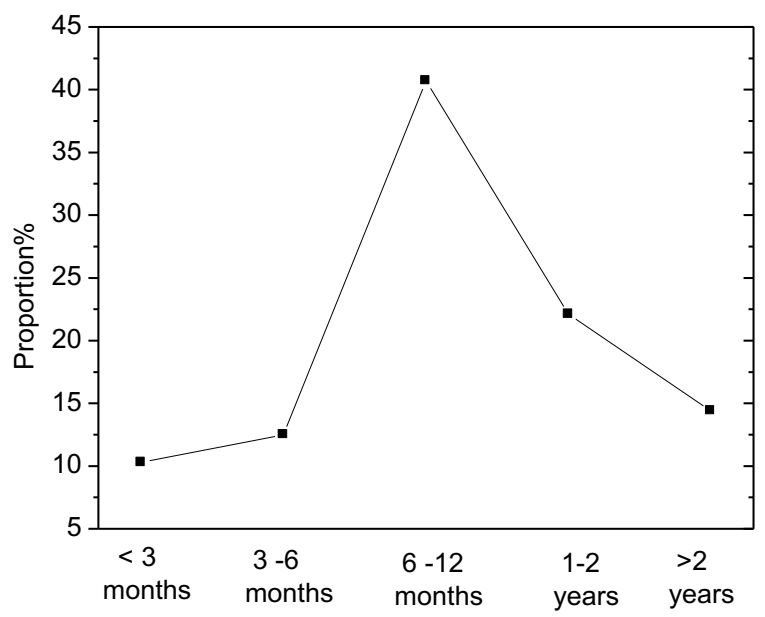

Fig. 2. Students' art skills before the college entrance examination 
Figure 3 gives the statistics of students' understanding of core literacy. $86.2 \%$ of the respondents have very little understanding of core literacy or have no understanding at all, and this situation is very detrimental to the core literacy cultivation and overall development of students.

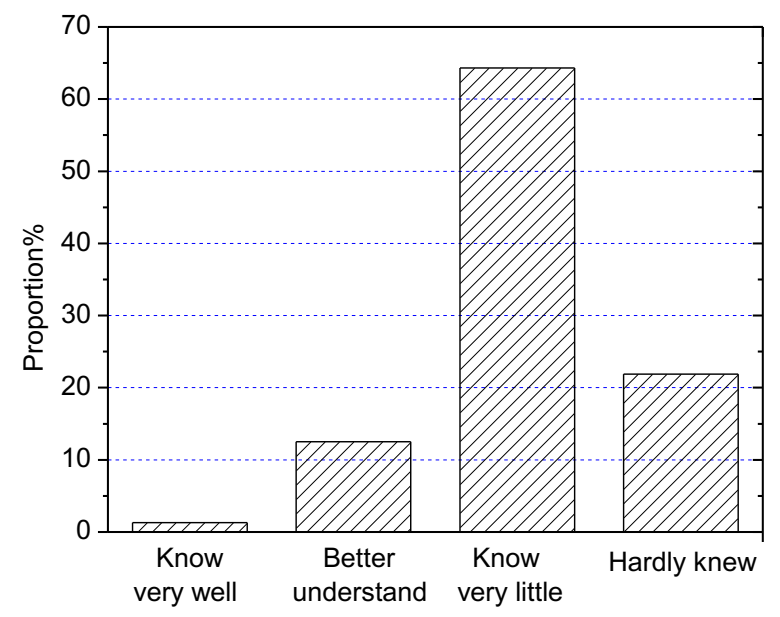

Fig. 3. Students' understanding of core literacy

\section{$2.2 \quad$ Teachers}

Table 1 lists the statistics of teachers' basic situation. According to the data in the table, the faculty structure of the art design major is unreasonable, the overall competence of the faculty is weak, teachers with a bachelor degree account for the most, the level of their professional titles is generally low, and more than half of the respondents haven't engaged in works related to the art design industry, and their understanding of the needs of the art design industry is insufficient. These situations have resulted in a detachment between the theory and practice during the teaching processing, and some teachers with industry work experience who are recruited from outside generally lack the basic theoretical teaching knowledge and experience.

Figure 4 shows the statistics of teachers' opinion on the impact of core literacy cultivation on students' comprehensive competence. As can been seen from the statistics, $78.3 \%$ of the teachers believe that core literacy cultivation is very important or important for enhancing students' overall competence. Through interviews, we further found that although the teachers have realized the importance of core literacy cultivation and they indeed have introduced training content of core literacy in their teaching intentionally, there isn't a sound or systematic training method yet. 
Table 1. Statistics of teachers' basic situation

\begin{tabular}{|l|l|l|}
\hline \multicolumn{2}{|c|}{ Category } & \multicolumn{1}{|c|}{ Proportion (\%) } \\
\hline Education & Undergraduate & 63 \\
\cline { 2 - 3 } & Postgraduate & 25 \\
\cline { 2 - 3 } & PhD student & 12 \\
\hline \multirow{4}{*}{ Title structure } & Teaching assistant & 11 \\
\cline { 2 - 3 } & Lecturer & 66 \\
\cline { 2 - 3 } & Associate Professor & 14 \\
\cline { 2 - 3 } & Professor & 9 \\
\hline \multirow{5}{*}{ Corporate work experience } & No & 62 \\
\cline { 2 - 3 } & $1-2$ years & 15 \\
\cline { 2 - 3 } & $2-5$ years & 13 \\
\cline { 2 - 3 } & Over 5 years 10 & 10 \\
\hline
\end{tabular}

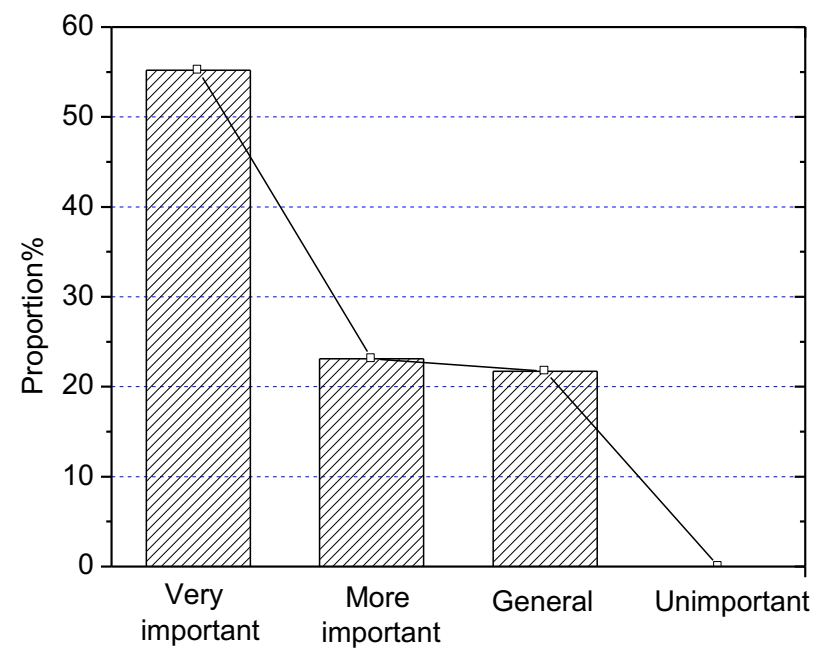

Fig. 4. Teachers' opinion on the impact of core literacy cultivation on students' comprehensive competence

\subsection{Teaching methods}

Table 2 shows the statistics of the common teaching methods adopted by teachers. Most of the art design teachers still use the traditional lecturing method to teach the courses; some of them also use a few other methods such as the project-based teaching method, case study method, situational teaching method, and discussion-based teaching method, etc.; however, through further interviews, it's found that since the classroom time is quite limited, in order to finish the teaching tasks in time, during the application process of these teaching methods, teachers still take the dominant role in the classroom, and students seldom have the opportunity to truly participate in the lecturing process, and student's dominant position has not been reflected. 
Table 2. Common teaching methods

\begin{tabular}{|l|c|}
\hline \multicolumn{1}{|c|}{ Teaching method } & Proportion (\%) \\
\hline Lecturing method & 75 \\
\hline Case study method & 45 \\
\hline Project-based teaching method & 38 \\
\hline Situational teaching method & 25 \\
\hline Discussion-based teaching method & 22 \\
\hline
\end{tabular}

Figure 5 shows the statistics of the main ways to cultivate the knowledge and ability of art design majors. According to the figure, currently the classroom teaching, offcampus internship, and school training are the main ways to cultivate the knowledge and ability of art design majors, wherein the classroom teaching is still the primary means, which shows that the phenomenon of emphasizing theory and neglecting practice still exists during the teaching process. After sorting and analyzing the interview results, it's also found that, most students think that the theories they learnt in school detach from the practice, after graduation, they couldn't adapt to their job posts directly, and there're still a lot to learn.

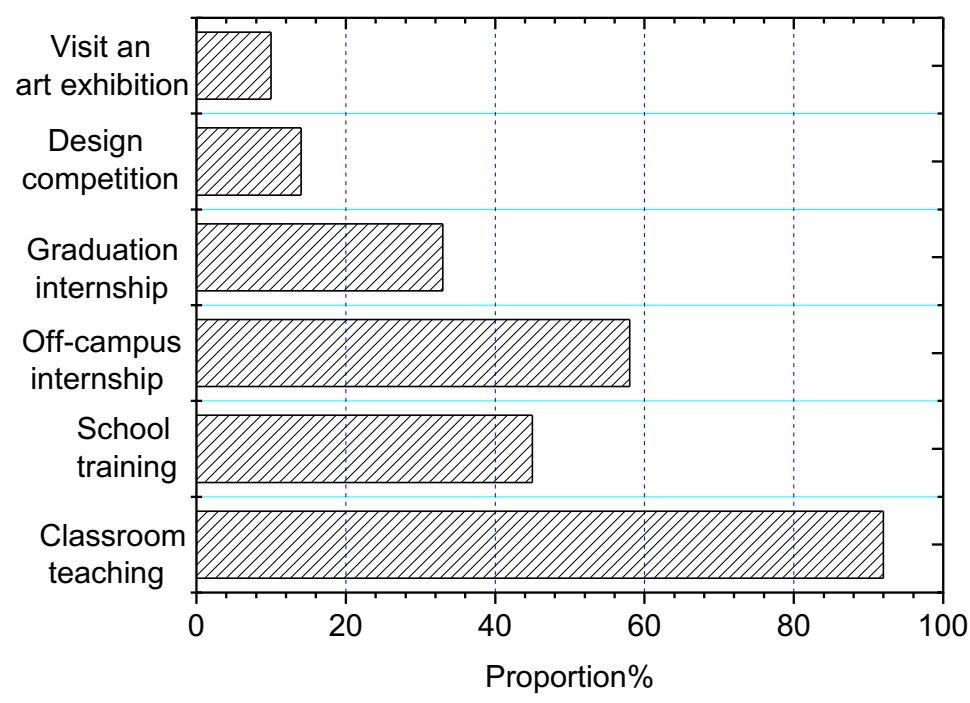

Fig. 5. Main ways to cultivate knowledge and ability of art design majors

As discussed above, the survey and interview results revealed a few problems with the art design education in Chinese colleges: (1) students generally have low cultural literacy; their interest in professional learning needs to be triggered; and they have little understanding of core literacy. (2) faculty structure is unreasonable, and the overall competence of the faculty is weak. (3) teaching methods are not as varied; theoretical learning detaches from the practical use. 


\section{Application of project-based hybrid learning mode in art design education from the perspective of core literacy}

Aiming at cultivating high quality art designers, improving students' core literacy, satisfying society's demand for art designers, and promoting the sustainable development of art design education, this paper proposed a project-based hybrid learning mode from the perspective of core literacy cultivation.

\subsection{The project-based hybrid learning mode}

Project-based learning. Project-based learning refers to the method in which teachers divide the learning content into several real projects and combine with reality to carry out the teaching activities, this mode is a student-centered learning mode [6], it emphasizes students' independent exploration and cooperative learning, it can effectively improve students' professional knowledge mastery efficiency, and enhance their comprehensive ability [7].

Hybrid learning. The hybrid learning mode is established based on the traditional classroom teaching, it can fully exert the advantages of online teaching and offline teaching. This mode emphasizes both the students' independent and cooperative learning based on resources, and the teachers' classroom lecturing; after applying hybrid learning, most students' effective learning depth could be increased [8]. The hybrid learning mode should realize the goals of three aspects, namely: online resources, offline activities, and process evaluations. In the era of Internet+, especially after the outbreak of the Covid-19 epidemic, the hybrid learning mode has become an inevitable trend for modern education [9].

Project-based hybrid learning mode. The project-based hybrid learning mode takes real projects as the themes to carry out practical teaching activities, it is divided into three stages: before class, in class, and after class. This mode is conductive to triggering students' learning initiative, improving the classroom teaching effect, cultivating students' core literacy, and enhancing their professional ability [10].

Before class: project import. Online resources are the prerequisite for the implementation of the project-based hybrid learning mode [11]. Therefore, the teachers should analyze the specific course teaching objectives based on the professional teaching goals before the class, figure out students' actual learning situations, and determine the project themes contained in the courses according to the actual designed learning tasks; moreover, they should prepare learning materials for these projects based on specific conditions of each project, including various videos, texts, PPT courseware, etc., and then post the learning materials and project tasks on online learning platforms, and check students' online learning status before the class, afterwards, they also need to exchange with students online and answer their questions [12].

Through online platforms, students can clarify the project tasks, carry out online independent and cooperative learning, complete online learning tasks assigned by teachers, and exchange with teachers and other students about the questions they have [13]. Figure 6 gives a diagram of the pattern of teaching activities before the class [14]. 
Before class : project import , knowledge acquisition

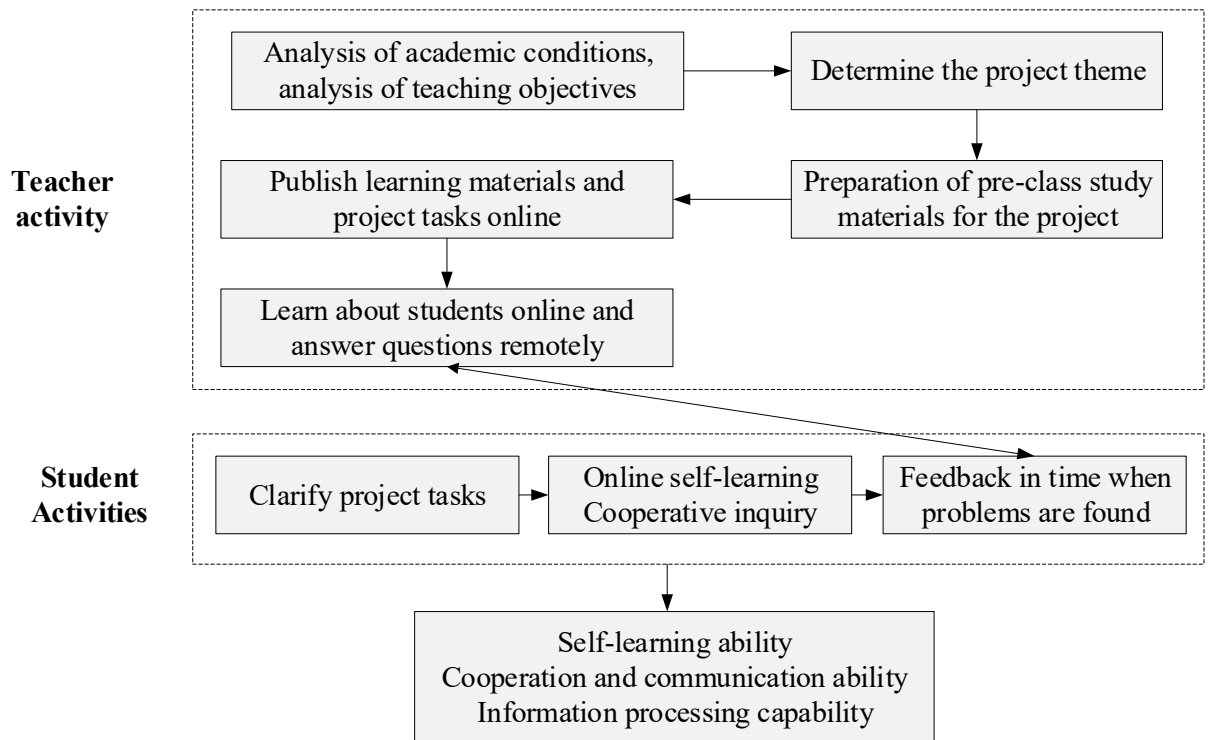

Fig. 6. Pattern of teaching activities before class

In class: project implementation and evaluation. Through online independent learning on the learning platforms, students have already mastered the basic knowledge required by the projects, thus the teachers don't have to spend a lot of time on explaining the knowledge, they just organize students to make discussions based on students' preclass online test results and the questions they raised, then they give instructions and answers to the difficulties encountered by students during knowledge point or project content learning. The class time is left for students to study independently or cooperatively, and complete the actual design project tasks assigned by teachers. In this process, teachers act the organizers of the class, they give personalized and targeted instructions to students who have doubts, then they comment on the project results completed by students, summarize the merits and shortcomings of the projects finished by students, conclude the content of the lesson, and help students deepen their understanding of the class content [15].

From students' perspective, they exchange with teachers and other students about the questions they encountered during the pre-class self-learning, then they finish the project tasks through self-exploration or team cooperation, show their design works to the entire class and give presentations; also, they are asked to evaluate their own works and comment on the design works of other students, in this way, students could learn from each other, make up for their own shortcomings, and new sparks will be generated during the collision of thinking [16]. Figure 7 gives a diagram of the pattern of teaching activities in class [17]. Figure 8 shows the project evaluation index system [18]. 


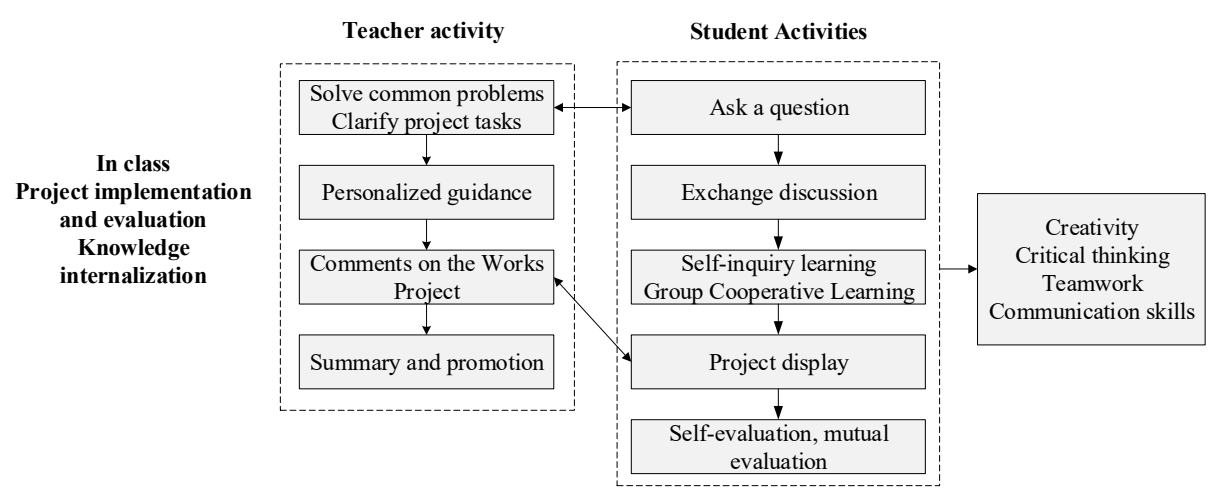

Fig. 7. Pattern of teaching activities in class

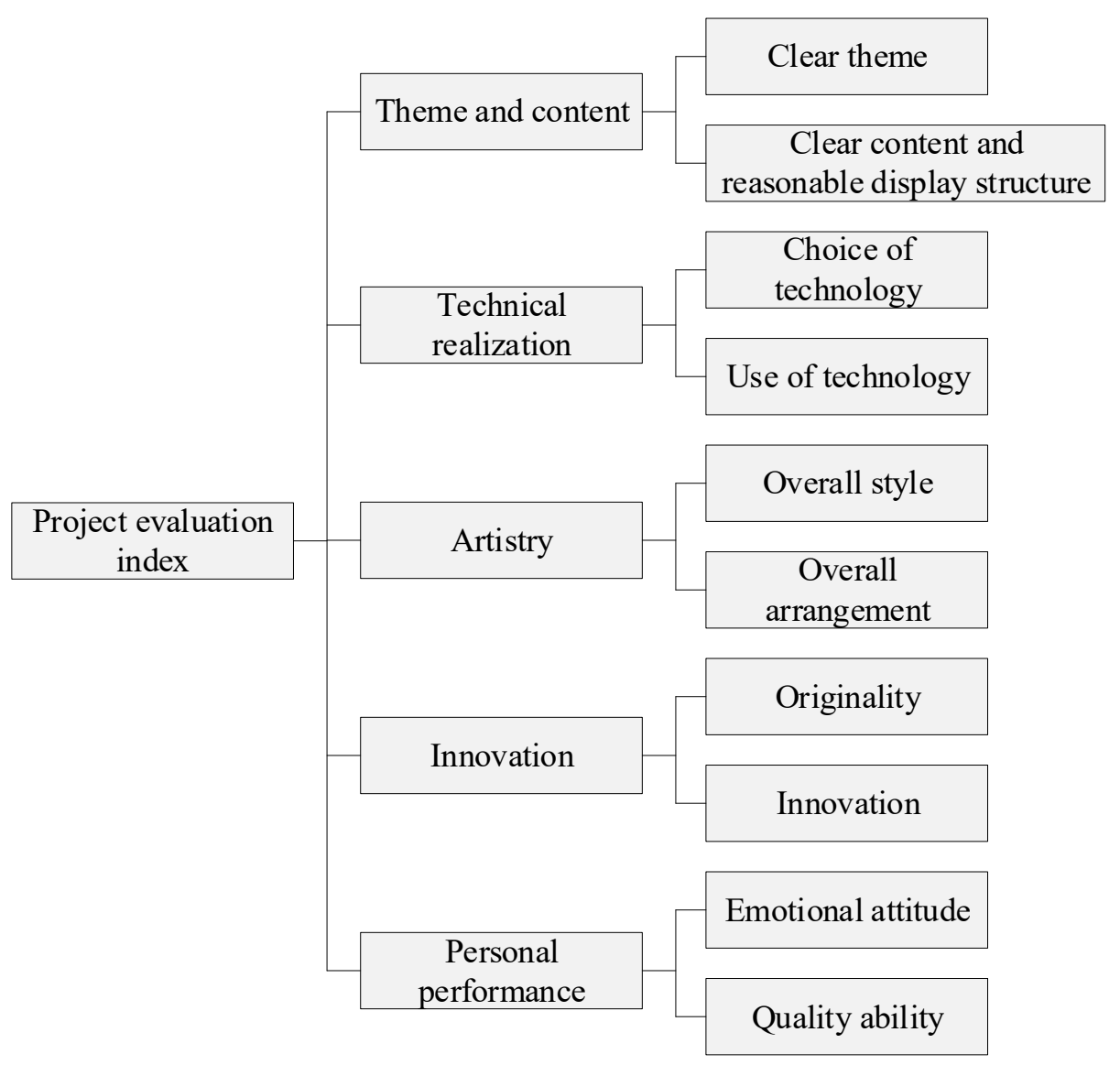

Fig. 8. The project evaluation index system 
After class: project summary. After class, teachers need to summarize and reflect on the classroom teaching activities and project completion situations of the students, figure out deficiencies in the projects, and perfect the online learning resources and classroom teaching activities; at the same time, they also need to make use of the online learning platforms, communicate and interact with students online, and answer their questions [19].

From the perspective of students, they need to use the online learning platforms to consolidate and review the knowledge points they learnt after the class, summarize and reflect on the evaluations given by teachers and other students in the class on their project results, and then modify and optimize their project results; for the difficulties they encountered during learning, they need to communicate with teachers and other students online, share their learning experience, and finally achieve knowledge solidification and sublimation [20]. Figure 9 gives a diagram of the pattern of teaching activities after the class.

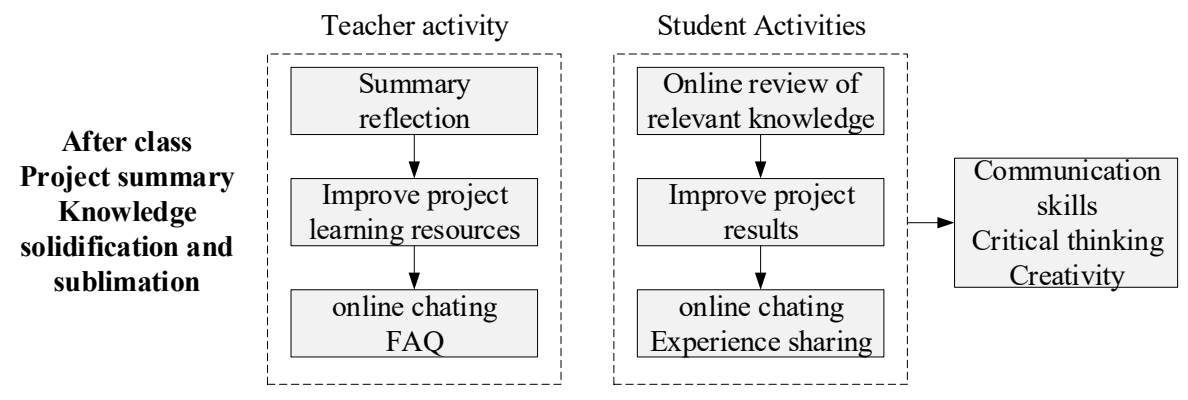

Fig. 9. Pattern of teaching activities after the class

\subsection{Application effect of the project-based hybrid learning mode in art design education}

To verify the effectiveness and feasibility of the proposed learning mode, a few art design majors from a college were selected as subjects to investigate the application effect of this proposed project-based hybrid learning mode in the teaching of the $A d$ vertising Design course. We designed a questionnaire on the teaching of the Advertising Design course, and two classes that had selected this course were taken as the subjects. One class with 35 students was taken as the test group, and was taught by a teacher using the newly proposed project-based hybrid learning mode; the other class with 32 students was taken as the control group, and was taught by the same teacher using the traditional project-based learning mode. The experiment had lasted for a semester, and there's no significant difference between the performance of the students in the two groups before the experiment.

Student satisfaction. Figure 10 shows the survey results of the satisfaction of students in the test group and the control group, as can be seen from the figure, the proportion of students in these two groups who hold a satisfied attitude accounts for $68.2 \%$ and $66.5 \%$, respectively, indicating that they prefer the project-based hybrid learning 
mode. However, there's not much difference in the satisfaction degree of students in the test and control groups, and this indicates that students are used to the traditional learning mode, and they do not reject it. Further investigation of the students in the control group showed that, more than $70 \%$ of the students expressed great expectations for the project-based hybrid learning mode, and they are willing to learn under this new mode.

Academic performance. Figure 11 shows the exam score distribution of students in the test group and control group. Both the two groups exhibit a normal distribution, but the exam scores of students in the test group are significantly higher than those of the control group, indicating that the project-based hybrid learning mode can effectively improve the teaching quality and students' academic performance.

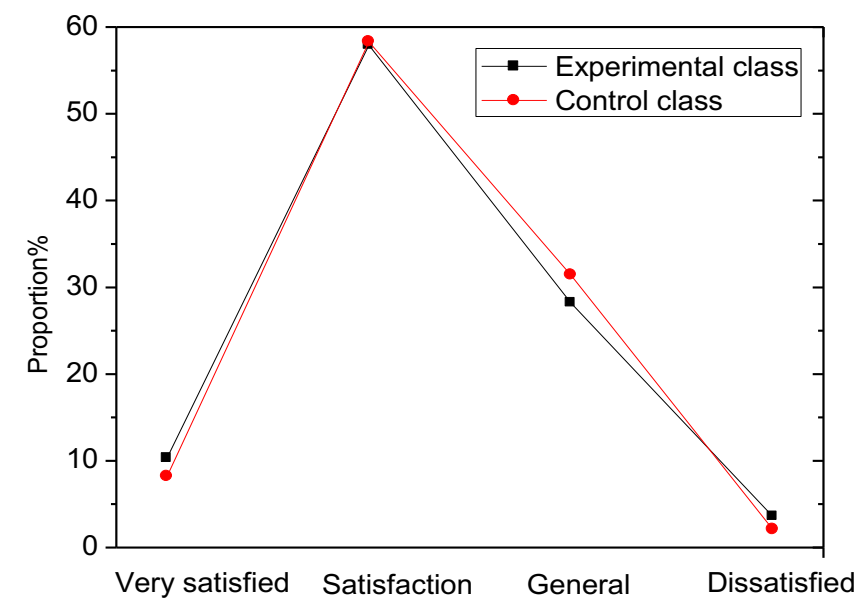

Fig. 10.Satisfaction of students in the test group and control group

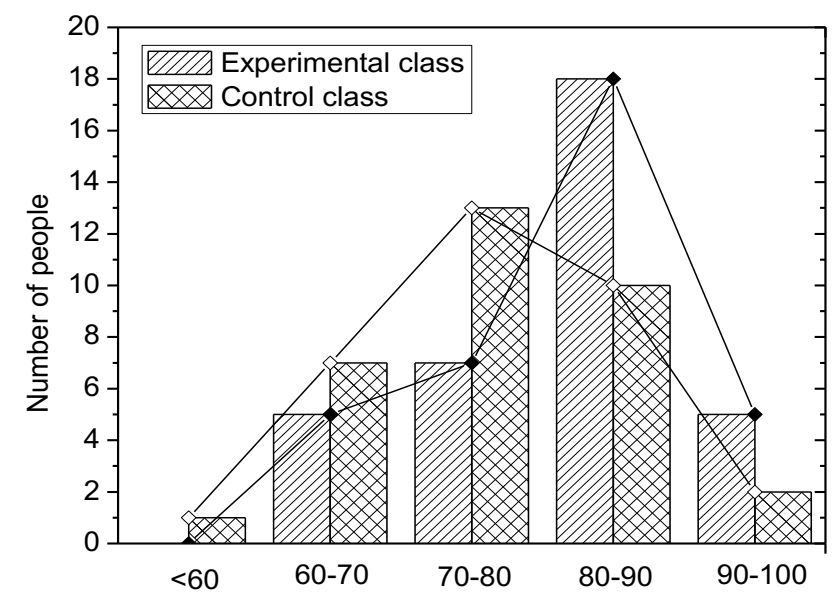

Fig. 11.Distribution of exam scores of students in the test group and control group 
Teaching effect. Figure 12 shows the survey results of students' opinion on the application effect of the project-based hybrid learning mode. Students who believe this mode is very helpful or helpful for improving their learning efficiency, core literacy, and professional ability accounts for $20.3 \%$ and $56.8 \%$, respectively; students who believe this mode is not that helpful only accounts for 3.5\%, and these students think that online learning has increased their academic burden, and they prefer the mode that teachers could give explanations in the class. In addition, the survey results showed that more than $80 \%$ of students believe that the project-based hybrid learning mode can improve their learning interest and willingness to participate in the classroom.

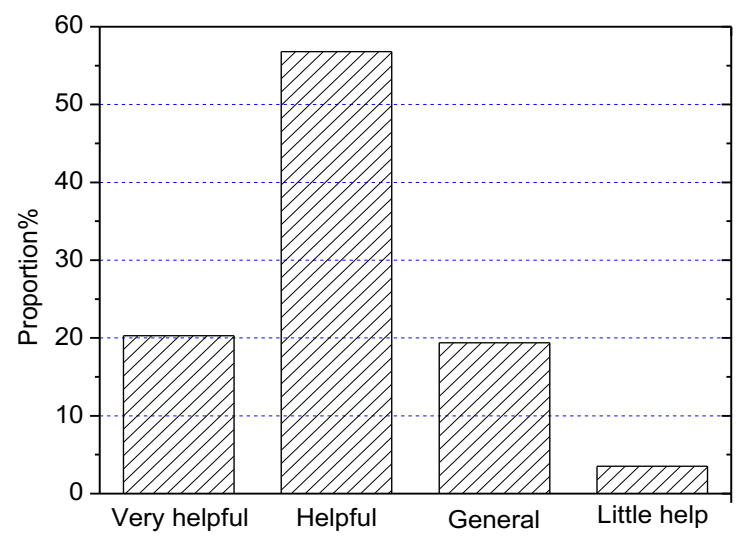

Fig. 12.Application effect of project-based hybrid learning mode

\section{Conclusion}

The art design major in colleges assumes the responsibility of cultivating high quality designers, and the continuing perfection and innovation of art design education mode is the prerequisite for the survival and development of art design education. In such context, this paper researched the current state of art design education in colleges and proposed a new learning mode, the specific conclusions are:

1. The survey results of the current state of art design education in colleges revealed a few problems, such as the students have a poor cultural literacy, a low interest in professional learning, and a weak understanding of the core literacy; the faculty has an unreasonable structure, an overall weak competence, a monotonous teaching method, and the detachment of theories from practices.

2. Based on the survey results, this paper proposed a project-based hybrid learning mode from the perspective of core literacy cultivation, and gave the specific implementation process of this mode.

3. Taking the Advertising Design course as the study case, the application effect of the project-based hybrid learning mode in art design education was investigated, and the survey results showed that the proposed mode can effectively improve the teaching quality of teachers and the core literacy and professional ability of students. 
Paper-Current State of Art Design Education in Colleges and a New Hybrid Learning Mode

\section{$5 \quad$ References}

[1] Gao, Y. (2020). Blended Teaching Strategies for Art Design Major Courses in Colleges, International Journal of Emerging Technologies in Learning, 15(24), 145-158. https://doi. org/10.3991/ijet.v15i24.19033

[2] Gürel, M. (2010). Explorations in teaching sustainable design: a studio experience in interior design/architecture. International Journal of Art \& Design Education, 29(2): 184-199. https://doi.org/10.1111/j.1476-8070.2010.01649.x

[3] Fox, B. (1981). Design-based studies: an action-based 'form of knowledge' for thinking, reasoning and operating. Design Studies, 2(1): 33-40. https://doi.org/10.1016/0142$694 x(81) 90027-2$

[4] Sawyer, R.K. (2017). Teaching creativity in art and design studio classes: A systematic literature review. Educational Research Review, 22: 99-113. https://doi.org/10.1016/j. edurev.2017.07.002

[5] Black, M. (1971). Design education in great Britain. Nature, 231(5295): 19-22. https://doi. org/10.1038/231019a0

[6] Danvers, J. (2010). Towards a radical pedagogy: provisional notes on learning and teaching in art \& design. International Journal of Art \& Design Education, 22(1): 47-57. https://doi.org/10.1111/1468-5949.00338

[7] Öztürk, M.N., Türkkan, E.E. (2006). The Design Studio as Teaching/Learning Medium-A Process-Based Approach. International Journal of Art \& Design Education, 25(1): 96-104. https://doi.org/10.1111/j.1476-8070.2006.00472.x

[8] Booth, T.L., Brubaker, T., Cain, T., Danielson, R., Varanasi, M.R. (1986). Design education in computer science and engineering. Computer, 19(6): 20-27. https://doi.org/10.1109/mc. $\underline{1986.1663249}$

[9] Hsueh, S.L., Zhou, B., Chen, Y.L., Yan, M.R. (2021). Supporting technology-enabled design education and practices by DFuzzy decision model: applications of cultural and creative product design. International Journal of Technology and Design Education. https://doi.org/10.1007/s10798-021-09681-7

[10] Veale, D., Ennis, M., Lambrou, C. (2002). Possible association of body dysmorphic disorder with an occupation or education in art and design. American Journal of Psychiatry, 159(10): 1788-1790. https://doi.org/10.1176/appi.ajp.159.10.1788

[11] Budge, K. (2016). Learning to be: The modelling of art and design practice in university art and design teaching. International Journal of Art \& Design Education, 35(2): 243-258. https://doi.org/10.1111/jade. 12060

[12] Shreeve, A., Sims, E., Trowler, P. (2010). 'A kind of exchange': learning from art and design teaching. Higher Education Research \& Development, 29(2): 125-138. https://doi.org/10. $1080 / 07294360903384269$

[13] Xu, Z. (2021). Teaching practice of environmental art design specialty based on fuzzy algorithm. Journal of Intelligent and Fuzzy Systems. https://doi.org/10.3233/jifs-189825

[14] Feng, W., Li, X. (2021). Innovative application research on the combination of art design and engineering practice education under the background of new media. International Journal of Electrical Engineering Education. https://doi.org/10.1177/00207209211003267

[15] Seery, M.K. (2015). ConfChem conference on flipped classroom: Student engagement with flipped chemistry lectures. Journal of Chemical Education, 92(9): 1566-1567. https://doi. org/10.1021/ed500919u

[16] Haghighi, H., Jafarigohar, M., Khoshsima, H., Vahdany, F. (2019). Impact of flipped classroom on EFL learners' appropriate use of refusal: achievement, participation, 
Paper-Current State of Art Design Education in Colleges and a New Hybrid Learning Mode

perception. Computer Assisted Language Learning, 32(3): 261-293. https://doi.org/10.1080/ 09588221.2018 .1504083

[17] Shih, H., Huang, S. (2020). College students' metacognitive strategy use in an EFL flipped classroom. Computer Assisted Language Learning, 33(7): 755-784. https://doi.org/10. $\underline{1080 / 09588221.2019 .1590420}$

[18] Ji, Y.P. (2011). Design education online: learning delivery and evaluation. International Journal of Art \& Design Education, 30(2): 176-187. https://doi.org/10.1111/j.1476$\underline{\text { 8070.2011.01689.x }}$

[19] Janet, J., Miles, M. (2010). Artemis: reinvigorating history and theory in art and design education. International Journal of Art \& Design Education, 28(1): 52-60. https://doi.org/ 10.1111/j.1476-8070.2009.01592.x

[20] Clement, R. (2010). Art and design education: theory into practice. Journal of Art \& Design Education, 7(3): 261-273. https://doi.org/10.1111/j.1476-8070.1988.tb00445.x

\section{Author}

Jing Liang, graduated from art design department of Hebei University of Science and Technology, received the master's degree in art from Hebei University in December 2009. She works at Art and Design Department of Shijiazhuang University of Applied Technology since July 2004. And her research interest is art and design.

Article submitted 2021-06-23. Resubmitted 2021-07-28. Final acceptance 2021-07-29. Final version published as submitted by the authors. 